\title{
Subcellular localization of yeast CDC46 varies with the cell cycle
}

\author{
Kevin M. Hennessy, Chris D. Clark, and David Botstein \\ Department of Genetics, Stanford University, Stanford, California 94305 USA
}

\begin{abstract}
The Saccharomyces cerevisiae CDC46 protein accumulates in the nucleus of nondividing interphase cells. Soon after the cell has become committed to division, there is a rapid disappearance of CDC46 protein from the nucleus. This shift is not a consequence of variation in total CDC46 protein levels and is associated with DNA replication at the $\mathrm{G}_{1}-\mathrm{S}$ boundary. We propose that the $C D C 46$ protein, which is required for DNA replication, becomes mobilized quickly from the cytoplasm into the nucleus as mitosis is completed and persists there until the next round of division is initiated. This partitioning of proteins in a cell cycle-dependent manner illustrates a general means of regulating events that must occur only once in each cycle, such as DNA initiation.
\end{abstract}

[Key Words: Nuclear signals; DNA replication]

Received September 7, 1990; revised version accepted October 16, 1990

The cell division cycle of all eukaryotic cells, whether a simple unicellular organism or from a mammalian tissue, requires a high degree of coordinated control. For instance, any attempts to separate incompletely replicated chromosomes is disastrous. The ability to keep order in the pathways that govern and carry out cell division, DNA duplication, and mitosis are thus of fundamental importance in all eukaryotes. Tremendous prog. ress has been achieved because of the recent recognition that several cell division cycle $(C D C)$ genes first identified in Saccharomyces cerevisiae encode conserved elements required for global control of the cell cycle in all eukaryotes (Wittenberg and Reed 1989; Nurse 1990). One component, identified as CDC2 in Schizosaccharomyces pombe and CDC28 in S. cerevisiae, acts in combination with a set of cyclically synthesized proteins known as cyclins (Draeta et al. 1989; Richardson et al. 1989). The cell division initiation, or "start," cascade has been conserved to such an extent that the controlling yeast and mammalian protein kinases are interchangeable (Beach et al. 1982; Lee and Nurse 1987; Wittenberg and Reed 1989|. Many of the signals that initiate the cycle, including nutritional status and the presence of intercellular factors, converge at the level of the $C D C 2 / C D C 28$ kinase (Courchesne et al. 1989; Elion et al. 1990). The targets of this kinase are then mobilized to carry out the cell cycle cascade (Moreno and Nurse 1990).

DNA replication is a central event that must be activated appropriately and in coordination with the rest of the cell cycle. Initiation at each replication origin is essential, but it must transpire only once per cycle. Despite the essential nature of this process and its importance in cell replication, some of the major constituents have been identified only recently (Burgers 1989;
Stillman 1989|. Eukaryotic DNA replication is quite distinct from the process used by prokaryotes. As a simple eukaryotic cell, $S$. cerevisiae provides an excellent system to study DNA replication and the cell cycle. Furthermore, the sophisticated genetics available in this system make possible the isolation of previously unanticipated elements and provide a vehicle for observing physiological effects of known components. A few yeast mutants, altered in the cell division cycle, already have been useful in characterizing key components involved in DNA synthesis. The two major DNA polymerases are encoded by the CDC17 and CDC2 genes (Budd et al. 1989; Sitney et al. 1989), whereas DNA ligase is encoded by $C D C 9$ (Johnston and Nasmyth 1978).

We have identified several new members of the DNA replication machinery in $S$. cerevisiae. Two of these, $c d c 45$ and $c d c 54$, were isolated as cold-sensitive mutations that arrest with a single large bud (Moir et al. 1982). Extragenic suppressors have been isolated that permit normal growth of either $c d c 45$ or $c d c 54$ in the cold and also arrest with a large bud at $37^{\circ} \mathrm{C}$. One gene, now called $c d c 46$, yields efficient suppressors of both $c d c 45$ and $c d c 54$, but in an allele-specific manner. The $c d c 46$ allele capable of suppressing $c d c 45$ cannot suppress $c d c 54$ and vice versa (Moir et al. 1982). This entire set of proteins is required for DNA replication, as judged by each of their mutant phenotypes $(\mathrm{K}$. Hennessy, unpubl.). We demonstrate here that the localization of $C D C 46$ protein shifts between the nucleus and the cytoplasm as cells progress through the cell cycle. This localization change is independent of total protein levels and represents a novel form of regulation appropriate for events that must occur once, and only once, in the cell division cycle. 


\section{Results}

DNA content of arrested cdc46 mutant cells

We have investigated whether $C D C 46$ is required for either initiation or synthesis of genomic DNA. Samples from exponentially growing diploid cultures of wild-type and homozygous cdc46-1 mutant cells were stained with propidium iodide and the DNA content for each cell was determined by flow cytometry. In exponentially growing wild-type diploid cultures, $35 \%$ of the cells have unreplicated (2n) DNA content, and $65 \%$ exhibit a duplicated (4n) DNA content (Fig. 1A). Mutant diploids homozygous for the temperature-sensitive $c d c 46-1$ allele display an unreplicated $(2 \mathrm{n})$ DNA content $3 \mathrm{hr}$ after shift to $37^{\circ} \mathrm{C}$, the nonpermissive temperature (Fig. $1 \mathrm{C}$ ), suggesting that arrest has occurred at a point in the cell cycle before DNA synthesis. At an intermediate time ( $1.5 \mathrm{hr}$ ) after shift to $37^{\circ} \mathrm{C}$, there is a substantial broad peak between $2 \mathrm{n}$ and $4 \mathrm{n}$ DNA content (Fig. 1B), sug. gesting that many of the cells have lagged in their DNA replication. There is no lag evident in either the wildtype culture at $37^{\circ} \mathrm{C}$ (Fig. $1 \mathrm{~A}$ ) or the $c d c 46$ culture at $21^{\circ} \mathrm{C}$ (not shown). By $3 \mathrm{hr}$, most of the cells that were in $\mathrm{S}$ phase at $1.5 \mathrm{hr}$ have completed one round of DNA synthesis and cytokinesis only to subsequently arrest in the

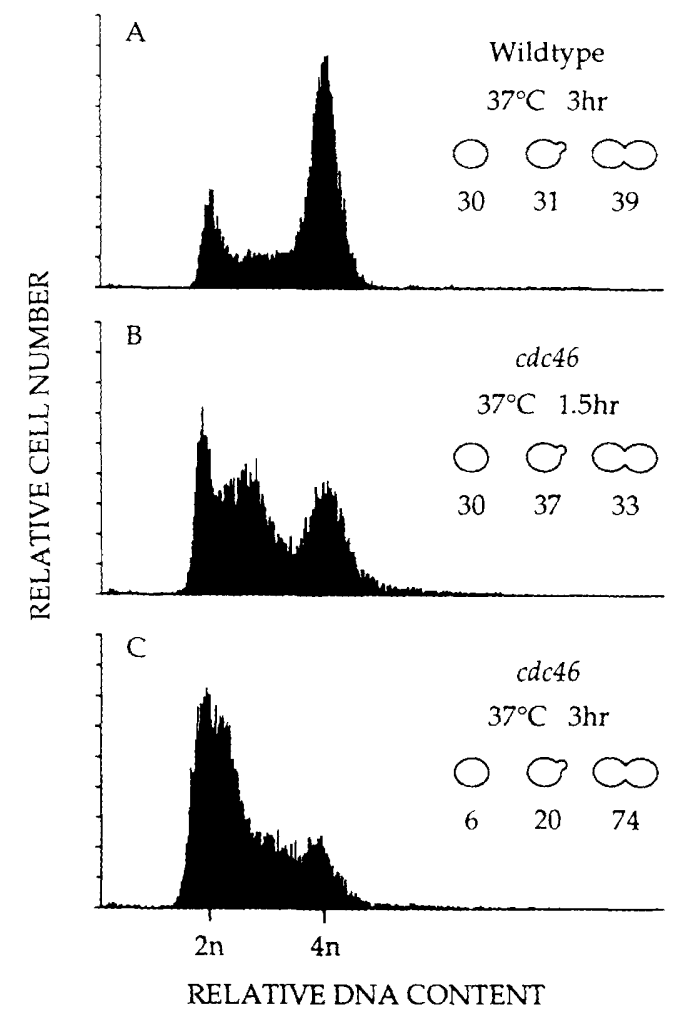

Figure 1. $C D C 46$ is required for DNA replication. The DNA content of wild-type and $c d c 46$ cells was determined by flow cytometry. Both homozygous $c d c 46-1$ or $C D C 46$ diploid strains were shifted from a permissive temperature of $23^{\circ} \mathrm{C}$ to the nonpermissive temperature of $37^{\circ} \mathrm{C}$. $(B$ and $C)$ Two time points taken from the same $c d c 46$ culture. To the right of each graph, the percent of cells in the culture at each stage of the cell cycle (unbudded, small budded, or large budded) is indicated. following cycle with a large bud and one-half the normal DNA content for a cell at this stage (Fig. 1C). Thus, cdc46 cells arrest with their DNA unreplicated, and we infer that DNA elongation is not blocked. More detailed interpretation of the DNA synthesis defect in $c d c 46$ cells is given in the Discussion, below.

Among the characterized $S$. cerevisiae cell division mutants, $c d c 7$, which is essential for DNA initiation, arrests with a phenotype similar to $c d c 46$ mutants, an unreplicated genome in a cell that has produced a single large bud (Pringle and Hartwell 1981). The fact that a cell morphology normally not present in growing populations accumulates in these mutant cells further supports the substantial body of evidence that the cell cycle involves the coordinated execution of several independent cycles and that cells can complete one portion of the cell cycle (cell growth) when another (DNA replication) is defective (Pringle and Hartwell 1981).

The order of CDC46 gene function within the cell cycle

The unusual cell cycle arrest of large budded cells with an unreplicated genome suggests that $C D C 46$ functions very early in the cell cycle, prior to or early in DNA synthesis. We have determined whether a $c d c 46$ mutation will prevent cells from completing the cell cycle after a block in DNA elongation is removed, as would be expected for a block in DNA initiation (Hartwell 1976). If the $C D C 46$ gene product can execute its function before the majority of DNA replication is complete, then the essential function supplied by $C D C 46$ should take place even if DNA replication is inhibited by hydroxyurea. A subsequent shift from hydroxyurea to the $c d c 46$ nonpermissive temperature should not affect completion of the cell cycle in this case.

We arrested an exponentially growing $c d c 46-1$ culture with hydroxyurea in liquid medium and then substituted this cell cycle block (Slater 1973) with that of the cdc46-1 cell cycle block by removing the hydroxyurea and placing the cells on an agar slab at the nonpermissive temperature for $c d c 46-1$. Photographs were taken of the cells before and after this second arrest on the agar slab to assess the progression of each cell through the cell cycle. Table 1 summarizes the results of this experiment. Over $90 \%$ of the cells placed at the nonpermissive temperature $\left(37^{\circ} \mathrm{C}\right)$ can recover from the hydroxyureainduced cell cycle block, complete one cell cycle, and arrest division during the second cell cycle. In addition to transferring the hydroxyurea-arrested cells to $37^{\circ} \mathrm{C}$, some were placed at the permissive temperature for $c d c 46$ to confirm that the hydroxyurea-induced cell cycle block is reversible and not lethal. A second aliquot of cells was placed on solid medium containing hydroxyurea to show that the hydroxyurea block is complete throughout the experiment. Consequently, we surmise that $C D C 46$ functions very early in the cell cycle, before DNA elongation. This is consistent with the early execution of the CDC46 function in the general unsynchronized cell cycle (D. Moir and D. Botstein, unpubl.). 
Table 1. Ordering the CDC46 and hydroxyurea cell cycle restrictions

\begin{tabular}{lccc}
\hline \multicolumn{1}{c}{ Shift } & $\begin{array}{c}\text { Total cells } \\
\text { examined }\end{array}$ & $\begin{array}{c}\text { Percent arrest in } \\
\text { first cycle }\end{array}$ & $\begin{array}{c}\text { Percent arrest in } \\
\text { second cycle }\end{array}$ \\
\hline $\mathrm{HU} \rightarrow 37^{\circ} \mathrm{C}$ & 93 & 8 & 92 \\
$\mathrm{HU} \rightarrow 26^{\circ} \mathrm{C}$ & 127 & 3 & \\
$\mathrm{HU} \rightarrow \mathrm{HU}$ & 151 & 95 & \\
\hline
\end{tabular}

${ }^{2} \mathrm{All}$ incubations with hydroxyurea were at $26^{\circ} \mathrm{C}$. Where a tem perature is indicated, incubation was in the absence of hydroxy. urea (HU).

\section{Identification of the $\mathrm{CDC} 46$ gene product}

We cloned the $C D C 46$ gene and localized the wild-type protein using antibodies generated against a CDC46$\operatorname{trpE}$ bacterial fusion protein. As described in Materials and methods, the gene was cloned by transforming a cdc46-1 mutant strain with a $S$. cerevisiae DNA library in the yeast vector $\mathrm{YCp} 50$, which carries a yeast centromere and replication origin for plasmid maintenance (Rose et al. 1987). One complementing plasmid, pRB541, has an insert of $15.6 \mathrm{~kb}$ capable of rescuing the temperature-sensitive lethality at $37^{\circ} \mathrm{C}$. The portion of pRB541 responsible for complementation was localized further by eliminating this activity with mini-Tn10-lacZ-kan ${ }^{R_{-}}$ URA3 (Tn10-LUK) transpositions (Huisman et al. 1987). All plasmid derivatives with transposon insertions within or immediately adjacent to a $1.1-\mathrm{kb} \mathrm{BamHI}$ fragment (Fig. 2) failed to complement, indicating that this fragment is internal to the gene. This internal $B a m H I$ fragment was subsequently used for both gene disruption and bacterial expression experiments.

To establish that the complementing plasmid pRB54l carries the $C D C 46$ gene, we constructed strains with a disruption at the $1.1-\mathrm{kb}$ BamHI fragment. The $1.1-\mathrm{kb}$ fragment was subcloned into the yeast-integrating plasmid YIp5 and used to transform a yeast diploid strain, DBY5450. Because this strain is heterozygous for the $c d c 46-1$ mutation, a disruption of the wild-type gene should unmask the temperature-sensitive phenotype if the $1.1-\mathrm{kb}$ fragment is exclusively $C D C 46$-coding sequence. Half of the transformants recovered were temperature sensitive, confirming that the mutation lies within the gene disrupted by the 1.1-kb BamHI fragment insertion. After sporulation and tetrad dissection of diploid transformants with temperature-sensitive (DBY4921) or wild-type (DBY4922) phenotypes, the viability of the spores was assessed. Only half of the spores were viable, and as expected, all of these (112 of 112) were uracil auxotrophs and able to grow at $37^{\circ} \mathrm{C}$, indi- cating that the integrated plasmid carrying the URA3 gene was completely linked to the lethality and that the temperature-sensitive copy of $c d c 46$ has been disrupted. When the temperature-sensitive diploid was dissected, all of the viable spores were temperature sensitive, as well as Ura ${ }^{-}$. Similar experiments with a strain that has the plasmid integrated into the URA3 locus (DBY5449) show that the plasmid itself has no effect on spore viability. Thus, CDC46 is an essential gene and the cloned $1.1-\mathrm{kb}$ BamHI fragment carries an internal portion of this gene, because it integrates exclusively at, and inactivates, the $C D C 46$ locus.

The same 1.1-kb BamHI fragment was used to construct a $C D C 46-\operatorname{tr} E$ fusion expression protein that we used to elicit rabbit antibodies against the $C D C 46$ protein (henceforth, CDC46p). The trpE hybrid proteins are easily enriched due to their insolubility and were purified further by SDS-PAGE. As described in Materials and methods, antibodies from two rabbits were affinity purified independently on a trpE-CDC46 column. After two consecutive affinity purifications, the antibodies react with a single $95-\mathrm{kD}$ protein band present in immunoblotted S. cerevisiae extracts (not shown, but see Fig. 7, below). Antibodies purified independently from both rabbits react with the same band on SDS-PAGE, identifying the $C D C 46$ product as a $95-\mathrm{kD}$ protein.

\section{Subcellular localization of $\mathrm{CDC} 46$}

Affinity-purified antibodies directed against CDC46p applied to a fixed exponential culture of wild-type yeast cells react with nuclei in a cell cycle-dependent manner as observed by immunofluorescence (Figs. 3 and 4). In the early stages of the cell cycle, prior to formation of a daughter cell, CDC46p is observed predominantly in the nucleus, although faint cytoplasmic staining is evident. Remarkably, once the bud has formed, the nuclear staining disappears. Nuclear staining reappears later in the cell cycle, in cells that have completed daughter cell growth and chromosome division. It should be stressed that all cells at each particular stage of the early cell cycle appear to stain in the same way, for example, nuclear staining in unbudded cells and cytoplasmic staining in small budded cells. However, not all the large budded, postmitotic cells have nuclear CDC46p staining. There are two classes of cells with this same gross physical morphology that can be differentiated by the localization of CDC46p. Because large budded cells often have an extended nucleus, we can see in them that staining of CDC46p is associated specifically with the DAPI staining region rather than being distributed
Figure 2. Restriction map of the CDC46 gene. A restriction map of the $C D C 46$ region is shown with the CDC46-coding region, and its orientation is indicated by the open arrow. The 1.1-kb BamHI fragment was used for gene disruption and bacterial expression as described in Materials and methods.

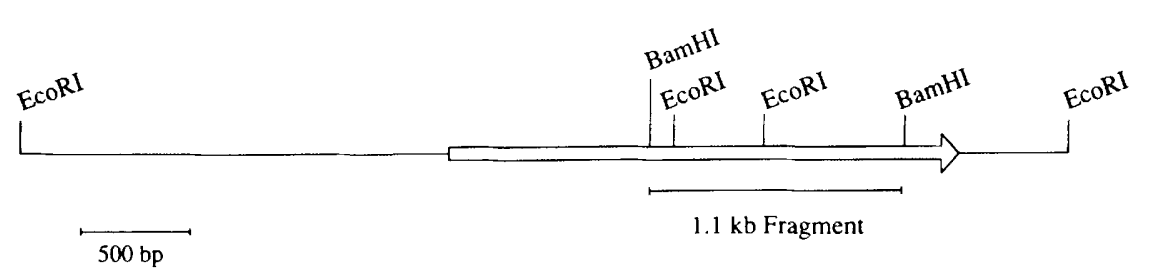



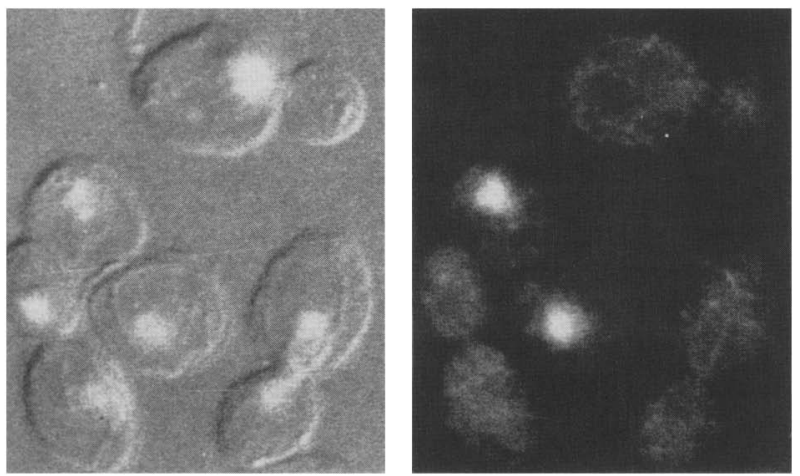

Figure 3. Nuclear localization of CDC46p in unbudded cells. Affinity-purified antibodies to $C D C 46$ were reacted with a population of wild-type $S$. cerevisiae cells and visualized by indirect immunofluorescence (right). The cells were also stained with an anti-tubulin monoclonal antibody to determine the position of the cell within the cell cycle (not shown), as well as DAPI and DIC (left).

throughout the entire nucleus. This is the kind of behavior that might be expected if CDC46p is a DNA-associated protein.

To clarify the basis for two classes of large budded cells, the timing of $C D C 46$ reappearance was studied relative to mitosis. The mitotic spindle was observed by staining cells with rhodamine-labeled anti-tubulin antibody in addition to FITC-labeled anti-CDC46 antibody and DAPI (Fig. 4). Cells were then photographed and grouped into one of four categories based on cell and spindle morphology: (1) unbudded, \{2\} small budded, $|3|$ large budded with long spindle, or (4) large budded with a disassembled spindle. The fraction of cells and their staining pattern for each of these four categories is shown in Figure 5 as part of a schematic representation that can account for CDC46 localization changes. Postmitotic cells, which have not yet completed cytokinesis, show nuclear CDC46p staining, whereas budded cells at earlier points in the cell cycle display no nuclear staining.

With the division of the large budded cells into two types based on the spindle morphology, we observe a close correlation between position in the cell cycle and presence of CDC46p staining in either nucleus or cytoplasm. We observe few, if any, cells showing intermediate staining in these unsynchronized cultures, implying that appearance of CDC46p in the nucleus during the last stages of division and the disappearance coincident with bud emergence are both rapid processes. This result suggests that the timing of the appearance and disappearance of CDC46p could be determined more exactly using cell cycle mutants. By using other cell division cycle mutants, the steps leading up to bud emergence and DNA replication can be separated from other concurrent processes, allowing the effect of each on CDC46 localization to be ascertained.

\section{Localization of CDC46 product in arrested cells}

Three $S$. cerevisiae cell division cycle mutants serve as landmarks to the steps prior to DNA synthesis: $\operatorname{cdc} 28$ defines the start point of the cell cycle /mutant cells arrest without a bud after shift to nonpermissive temperature); $c d c 4$ and $c d c 7$ define later steps in the cycle cells, and mutant cells arrest with buds at the nonpermissive temperature (Pringle and Hartwell 1981). The three gene functions are required in the order $c d c 28, c d c 4$, and $c d c 7$ (Hereford and Hartwell 1974). We used mutants in these genes to define, at higher resolution, the stage of the cell cycle where $c d c 46$ nuclear staining disappears.

In each case, haploid mutant cells were shifted to their nonpermissive temperature for a period long enough to arrest most of the cells with the morphology typical of that mutation. Immunolocalization with the affinitypurified anti-CDC46p antibodies showed that nuclei in arrested cells carrying $c d c 28$ and $c d c 4$ displayed nuclear staining while $c d c 7$ cells showed an intermediate phenotype, with no cells showing strong nuclear staining and most cells showing weak cytoplasmic staining (Fig.
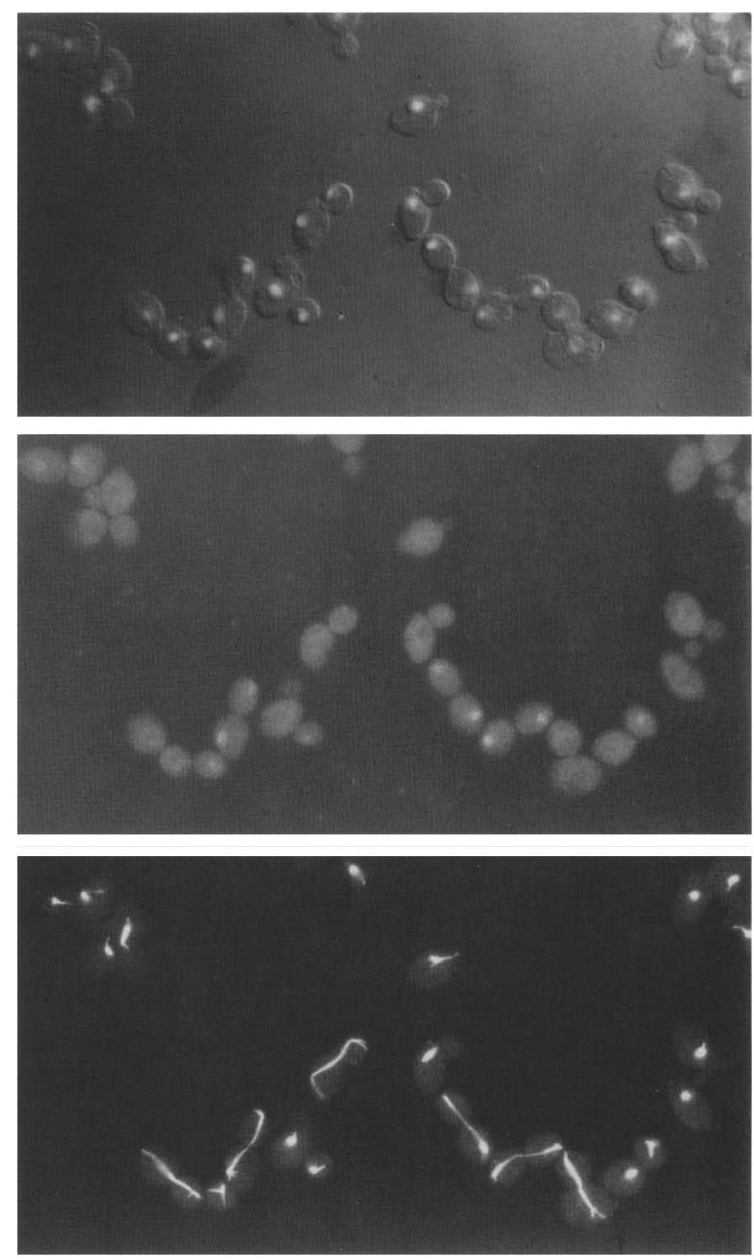

Figure 4. Localization of the $C D C 46$ product is cell cycle dependent. Affinity-purified antibodies to $C D C 46$ were reacted with a population of wild-type $S$. cerevisiae cells and visualized by indirect immunofluorescence (middle). In addition, the cells were stained with an anti-tubulin monoclonal antibody to determine the cell cycle position of each cell (bottom), as well as DAPI and DIC (top). 


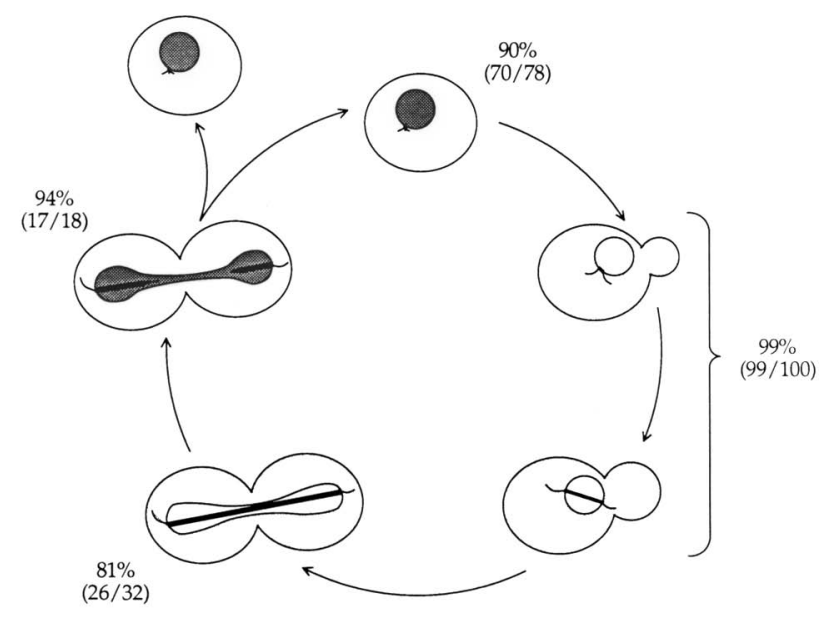

Figure 5. Fraction of nuclear-staining cells during each stage of the cell cycle. Two hundred cells, stained as in Fig. 4, were grouped by their position in the cell cycle and then scored as either $C D C 46$ nuclear-staining positive or negative on photos. The shaded areas schematically summarize one model to explain the results. The number (and fraction) of cells with CDC46 localized in the schematically represented subcellular location is indicated for each portion of the cell cycle: unbudded, small budded, large budded with an intact spindle, or large budded with mitosis completed.

6). From these results we can infer that the disappearance of CDC46p antigen from the nucleus occurs at some time after the execution points of $c d c 4$, and possibly near the execution point of $c d c 7$.

In the same way we tested many mutations that define later steps in the cell cycle, including some that affect DNA synthesis (cdc9, cdc2, and $c d c 17)$, mitosis (tub2, cdc16, cdc20, and $c d c 31)$, or late mitotic events ( $c d c 14, c d c 15$, and $c d c 5$ ) (Pringle et al. 1981). All of these displayed cytoplasmic staining in arrested cells and no staining in the nucleus. From these results we can infer that the disappearance of CDC46p antigen occurs before the execution point of $c d c 17$, that is, between $c d c 4$ and $c d c 17$, possibly at about the same time as $c d c 7$. It is worth noting here that $C D C 17$ encodes one of the major nuclear DNA polymerases of yeast (Carson 1987; Budd et al. 1989|. The studies with these mutants indicate that the disappearance of CDC46p antigen from the nucleus is not associated with bud formation or mitosis. However, there is a correlation between loss of CDC46p from the nucleus and the beginning of $S$ phase, making attractive the idea that CDC46p disappearance is coincident with the initiation of DNA synthesis. In normal wild-type cells, this event occurs at the time of bud emergence just when the CDC46p staining disappears from the nucleus (Fangman et al. 1981).

None of the mutations we tested show nuclear staining like the class of large budded cells that have broken down their spindle and show nuclear CDC46p antigen. The current set of $c d c$ mutations affecting late events apparently contains none that separates these two classes. Staining with anti-CDC46p antibody (along with careful examination of the spindle/ remains the only way to follow this step in the cell cycle.

\section{Localization by cell fractionation}

Immunolocalization studies represent only one way in which the presence of a protein can be followed. To confirm our results by a different method, we isolated nuclei from cells at various stages of the cell cycle and assayed the relative CDC46p content by immunoblotting analysis. Wild-type cells were arrested at either of two well-defined stages in $G_{1}$ phase with $\alpha$-factor or in $M$ phase (mitosis) with a cold-sensitive $\beta$-tubulin mutant, tub2-104. These cultures were then lysed and fractionated into a crude "nuclear" pellet and a soluble "cytoplasmic" fraction by centrifugation. DAPI staining of each fraction was used to assess the presence of nuclei. Samples of each fraction were then adjusted so that the same cell equivalent was present, resulting in much less total protein in the fractions containing nuclei. Figure 7 shows that $\alpha$-factor-arrested cells accumulate CDC46p in the nuclear fraction. In contrast, when cells are arrested in mitosis with a $\beta$-tubulin defect, most of the $\mathrm{CDC} 46 \mathrm{p}$ is found in the cytoplasmic fraction. This confirms CDC46 localization based on immunolocalization by microscopy.

\section{Total levels of CDC46p}

Cyclical expression and degradation of the CDC46 product could explain the observed staining patterns, that is, the CDC46 product could be a cyclin-like protein (Minshull et al. 1989). We examined the total level of CDC46 in a synchronized population of wild-type yeast cells through two cell cycles after removing an $\alpha$ factor block. Reasonably good synchrony was achieved in this experiment: Over $85 \%$ of the cells had a long mitotic spindle $80 \mathrm{~min}$ after removal of the $\alpha$-factor. Immunoblotted protein samples taken from the synchronized culture at $10-\mathrm{min}$ intervals were reacted with anti-

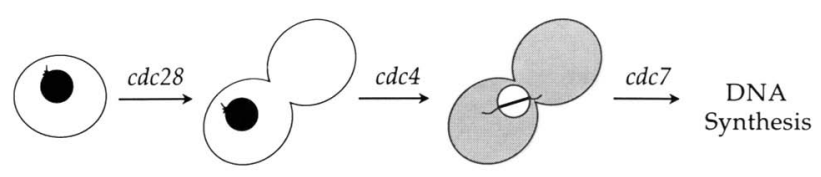

Figure 6. Localization of the CDC46 product in cells arrested at different points in the cell cycle. Affinity-purified antibodies to $C D C 46$ were reacted with populations of mutant $S$. cerevisiae cells, as described in Fig. 4, that have been arrested at points in the cell cycle defined by the indicated $c d c$ mutants. The results are shown schematically here. Mutations in start, as defined by $c d c 28$, give a strong nuclear staining and apparently accumulate the $C D C 46$ product in the nucleus. Unlike the wild-type populations, $C D C 46$ nuclear staining is present in budded cells that have been arrested with a $c d c 4$ defect $\mid \mathrm{al}$ though shown here as a single large bud, $c d c 4$ continues to bud in the arrested statel. The last mutant ordered prior to DNA replication is $c d c 7$, which shows a $C D C 46$ nuclear localization. All other $c d c$ mutants observed, including $c d c 2, c d c 9, c d c 16$, $c d c 31, c d c 5, c d c 14$, and tub2, show cytoplasmic accumulation of $C D C 46$ product, as evidenced by immunofluorescence. 


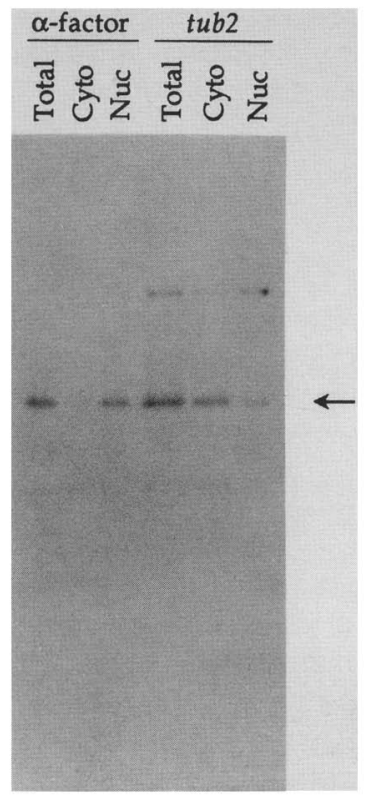

Figure 7. CDC46 fractionates in different compartments at distinct points of the cell cycle. Two cultures of arrested $S$. cerevisiae were divided into crude nuclear and cytoplasmic fractions. One culture was arrested with $\alpha$-factor, a point in the cell cycle that shows prominent nuclear staining. The second carries a cold-sensitive mutation in the $\beta$-tubulin gene and arrests with nuclear exclusion of CDC46 staining. Shown is a Western blot of these fractions, as well as a sample of the lysate prior to fractionation for each arrested culture that has been reacted with anti-CDC46 sera. Each of the samples has been normalized to have the same number of cell equivalents in each lane.

$C D C 46$, as well as anti- $\beta$-tubulin and anti-actin antibodies, to calibrate for the amount of protein loaded in each lane (Fig. 8). Although there are discernible fluctuations (quantitatively about twofold) in the amount of CDC46p, the changes relative to actin are small except for the initial increase after the removal of $\alpha$-factor. Thus, the differences seen in localization are not simply a reflection of degradation of a large fraction of the total CDC46p in the cell.

\section{CDC46 mRNA is differentially expressed during the cell cycle}

Despite the evidence that cyclical synthesis and degradation cannot alone account for the cyclical changes in CDC46p localization, we undertook a study of the levels of CDC46 mRNA through the cell cycle. We identified a single transcript of $2.3 \mathrm{~kb}$ in exponentially growing cells (Fig. 9, lane 1). To determine whether CDC46 mRNA levels change during the cell cycle, we synchronized a DBY1826 culture using $\alpha$-factor arrest. After $3 \mathrm{hr}$ of incubation in the presence of $\alpha$-factor, the CDC46 transcript is still present (Fig. 9, lane 2). Thirty minutes after release from $\alpha$-factor arrest, the mRNA level has decreased eightfold (Fig. 9, lane 4). By $60 \mathrm{~min}$, the level has increased back to that seen in the exponential culture.
To control for the levels of mRNA on each lane, the blot also was hybridized to a probe specific for the actin (ACT1) gene. Another probe for the histone $\mathrm{H} 2 \mathrm{~B}$ (HTB2) transcript, which is transiently expressed during $S$ phase, indicates the period of DNA replication and testifies to the degree of synchrony within the culture. Normalization to these bands shows that the increase in CDC46 transcript is cell cycle specific and indicates that although there are no large fluctuations in the protein levels once the cell cycle has commenced, the transcript is nevertheless regulated and most of the synthesis of CDC46 mRNA occurs in small budded cells.

\section{Protein levels of CDC46 in mutant cells}

$c d c 46$ mutant cells lack nuclear CDC46p staining at the nonpermissive temperature. Because this result suggests that the mutant defect is due to a lack of CDC46p in the nuclear compartment, we looked at the total levels of CDC46p in cells held at permissive or restrictive temperatures (Fig. 10). The level of CDC46p is consistently reduced to one-half the amount of wild type at the nonpermissive temperature, whereas the levels under permissive conditions resemble those in wild-type cells.

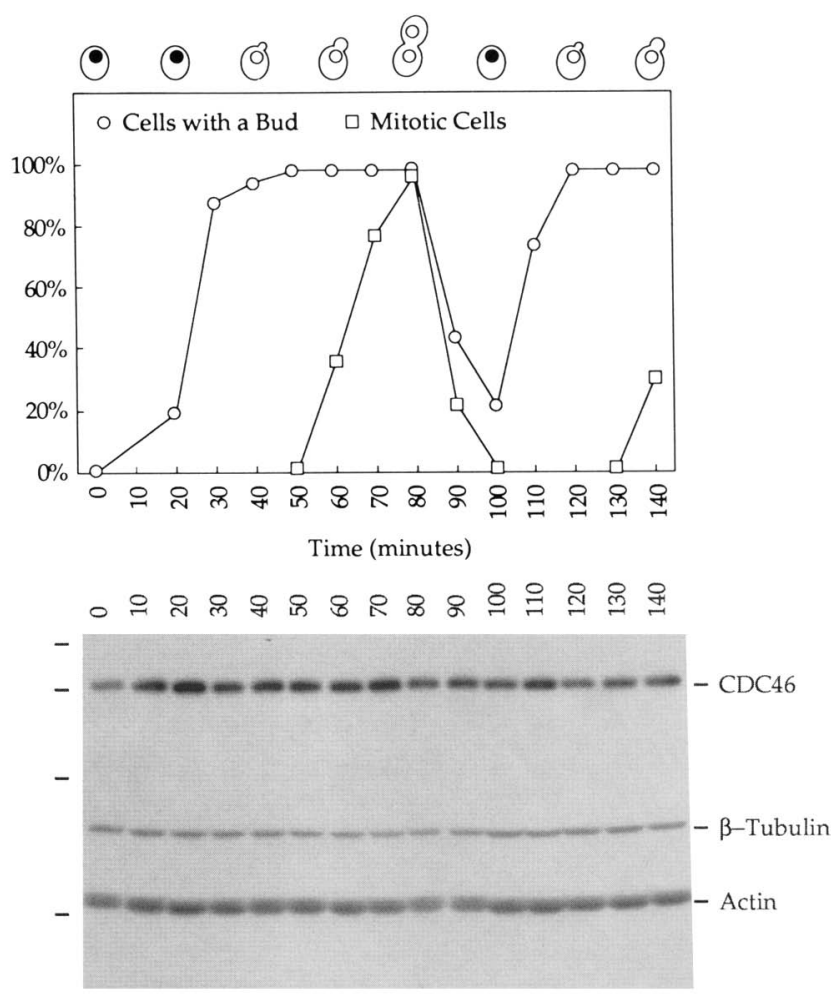

Figure 8. $C D C 46$ is not a true cyclin. A wild-type culture of $S$. cerevisiae was synchronized with $\alpha$-factor. Protein samples were taken prior to, and every $10 \mathrm{~min}$ after, release into fresh media. (Bottom) An immunoblot of those samples that have been reacted with antibodies to $C D C 46, \beta$-tubulin, and actin. The graph indicates the percent of cells in the culture that are budded and those in mitosis at each of the times that samples were taken. $(T o p)$ The type of cell morphology and whether CDC46p localizes to the nucleus. 

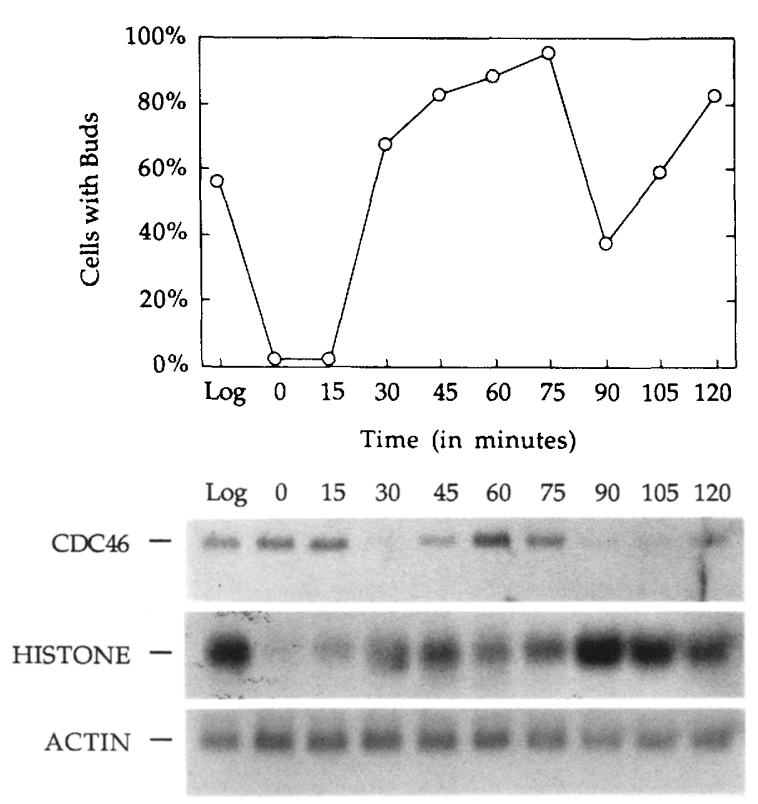

Figure 9. Northern analysis of CDC46-specific RNA during a synchronous cell cycle. Four micrograms of total RNA isolated from strain DBY1826 was run per lane. RNA was extracted as follows: During logarithmic growth in YEPD (lane 1); after $3 \mathrm{hr}$ of incubation in the presence of $\alpha$-factor (lane 2); every $15 \mathrm{~min}$ after release from $\alpha$-factor arrest (lanes 3-10). The Northern blot was probed sequentially with $H T B 2-, C D C 46-$, and ACT1specific probes. HTB2 mRNA is $\sim 0.6 \mathrm{~kb}, A C T 1$ mRNA is 1.4 $\mathrm{kb}$, and $C D C 46$ mRNA is estimated to be $2.3 \mathrm{~kb}$. The graph represents bud counts. At least 200 cells were scored for each time point.

This is true for three different alleles of $c d c 46$, and the change in levels independently corroborates that the $95-\mathrm{kD}$ protein is CDC46p. We infer that overall depletion of CDC46p in the mutant cells results in both the cell cycle defect and the failure to see nuclear staining.

\section{Discussion}

\section{CDC46 function is required for DNA synthesis}

A particularly useful characteristic of budding yeast is the ease with which many defects in the cell cycle can be identified by their arrest phenotype and readily distinguished from general metabolism defects. Conditional mutations in either DNA polymerase or tubulin, for example, result in a large bud attached to the mother cell at the restrictive temperature, giving rise to a growing, dumbbell-shaped cell. However, because both $S$-phase and M-phase cell division cycle $\langle c d c\rangle$ defects give rise to this same large bud arrest phenotype, it has been difficult to distinguish between mutations in these two processes. The application of flow cytometry (Hutter and Eipel 1978) now permits quick determinations of the DNA content in a cell cycle-arrested yeast cell. Flow cytometry surveys the gross level of DNA in each cell (including that residing in the mitochondria) and in this case, has unambiguously identified a defect in S phase, the DNA replication portion of the cell cycle, in cdc46 mutants. The lack of significant DNA synthesis in the arrested $c d c 46$ mutant is consistent with the shift in $C D C 46$ localization that occurs early in $\mathrm{S}$ phase.

DNA replication proceeds in two stages: initiation of the replication fork and elongation of the new strands. Because eukaryotic DNA synthesis is initiated at multiple origins, it is impossible to distinguish, based solely on the DNA content, between a cell with only half of its replication origins completely elongated and another cell that has every origin only half-elongated. As a result, a partial defect in either initiation or elongation can lead to an accumulation of cells with a DNA content intermediate between that of diploid cells with unreplicated $(2 n)$ or fully replicated $(4 n)$ chromosomes. So, while the peak of $c d c 46$ cells with a DNA content between $2 n$ and $4 n$ (Fig. 1B) attests unambiguously to an $S$ phase defect, this "lag" in $S$ phase does not distinguish incomplete initiation from an elongation failure. In the end, the cells complete DNA elongation and cytokinesis, as the final cdc46 arrest state is a large budded cell with an unreplicated genome.

Once $c d c 46$ cells enter into $S$ phase, they can continue on through the cell cycle to finally arrest in $G_{1}$, a phenotype more compatible with a DNA initiation defect than a failure in DNA elongation. The ability of $C D C 46$ to execute its function during a hydroxyurea-induced DNA elongation block implies that CDC46p is required before DNA elongation, at the initiation step.

\section{Possible function of cell cycle-dependent nuclear localization of CDC46p}

Recently, combined biochemical and genetic approaches

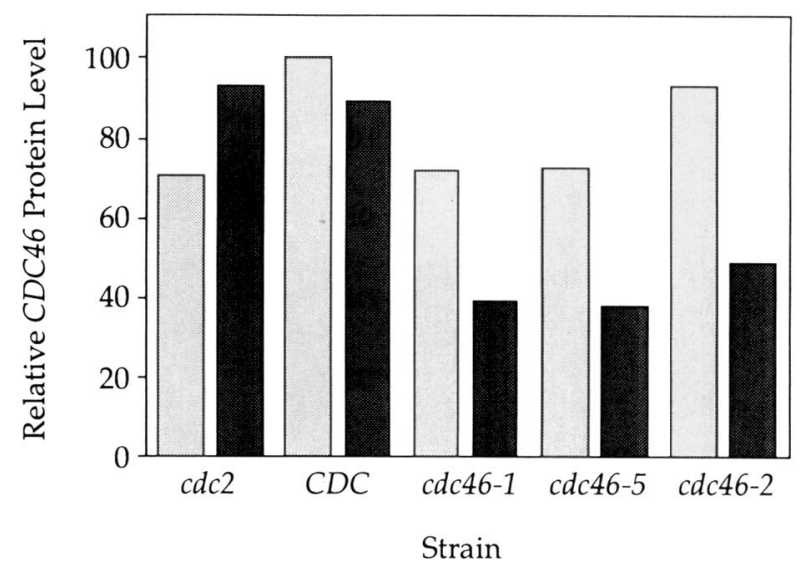

Figure 10. The level of $C D C 46$ protein is reduced in $c d c 46$ mutants. The level of CDC46p in several cell cycle mutants, including three alleles of $c d c 46$, was measured for cultures held at the permissive $\left(21^{\circ} \mathrm{C}\right.$, light shading $)$ or restrictive $\left(37^{\circ} \mathrm{C}\right.$; dark shading) temperatures for $3 \mathrm{hr}$. Protein from each culture was separated on SDS-PAGE, blotted, and probed with antibodies against CDC46p and actin. The level of each was determined by densitometry. $C D C 46$ levels were normalized to actin and then wild-type levels. 
have led to substantial progress toward understanding cell cycle control (Lewin 1990; Nurse 1990). The regulation of CDC46 function provides an example of a novel and potentially general regulatory mechanism, one in which subcellular localization supplements transcriptional and translational controls. In the present case, we have shown that the function of CDC46 is required in the initial steps of DNA synthesis. The pattern and timing of CDC46p localization are consistent with this result, as antigen disappears from the nucleus at exactly the time that the function is required. It seems likely that the properties that make it possible for CDC46p to be in the nucleus at the appropriate time are representative of the regulatory stringency required for ordered events in the cell cycle to occur in the correct sequence. Thus, we see that the protein is synthesized a considerable time before it is required but not present at its putative point of action until the right moment.

The possibility that the cell cycle-dependent localization of $C D C 46$ has an important regulatory function must be considered. We suggest that it might play a regulatory role that bridges and couples two cell cycles: An event late in mitosis (entry into the nucleus) triggers an event (initiation of DNA replication) that must occur in the next cycle. The disappearance from the nucleus thereafter guarantees that there is no residual function to initiate another round accidently. Blow and Laskey (1988) have provided a model that describes a regulatory pathway that is needed to explain how the initiation of DNA replication occurs once and only once at each of the multiple origins within a eukaryotic nucleus. The cyclic nuclear localization of $C D C 46$ and the essential role that $C D C 46$ plays in DNA replication is consistent with such a model.

It should be noted that other proteins have functions that might also be required in the nucleus just once in the cell cycle. Preliminary results concerning SWI5, a gene involved in the genetic events behind mating-type switching in yeast (which occurs in the nucleus at about the time of initiation of DNA replication; Nasmyth et al. 1987) suggest cyclical localization of the gene product entirely analogous to the cyclical localization found for CDC46p (Lewin 1990; Nasmyth et al. 1990).

\section{Possible mechanisms for cell cycle-dependent changes in localization of CDC46 product}

Before attempting an explanation of the nuclear appearance and disappearance phenomena described for CDC46p antigen, it is worth recapitulating the basic facts that act as boundary conditions to any model.

First, we found little fluctuation in overall levels of antigen in the cell. While the total amount increases as the cells come out of $\alpha$-factor arrest, the increase is threefold and does not correlate with the changes seen by immunofluorescence. More specifically, while the levels of total protein are rising at $20 \mathrm{~min}$ (Fig. 8), there is little or no nuclear staining in wild-type cells during this portion of the cell cycle. After this initial rise, the levels of total CDC46p remain relatively constant well into the second cell cycle. The lack of fluctuation in protein levels essentially rules out a cyclin-like mechanism for $C D C 46$, in which levels change rapidly and go through great extremes (for review, see Minshull et al. 19891.

Second, we found that synthesis of the protein is likely to be cyclical, as judged from the cyclical variation in the level of CDC46 mRNA, which is most abundant late in mitosis. These variations are timed in such a way that they alone cannot account for the variation seen in nuclear staining. Any model for these phenomena will have to reconcile the generally constant level of total antigen with the clear cyclical variation in the level of mRNA.

Third, the changes in localization observed by immunofluorescence are consistent with the results of fractionation experiments, thus making relatively unlikely localization-specific changes in epitope as opposed to changes in abundance of the protein. When crude fractionations are done on yeast cells arrested in $G_{1}$ (with $\alpha$-factor) or $\mathrm{M}$ (with tub2-104 mutation), there is a difference in localization: CDC46p is present in the nucleus in the former case and in the cytoplasm in the latter. This observation agrees perfectly with the immunofluorescence results; $\alpha$-factor-arrested cells stain the nucleus brightly and show little diffuse cytoplasmic staining, whereas the tubulin-arrested cells display cytoplasmic staining and nuclear exclusion. Because there is an overall increase of CDC46p in tub2-arrested cells, it may be more appropriate to conclude that the site of $C D C 46$ accumulation rather than its localization has changed. Because both types of arrest give rise to cells that show strong immunofluorescent staining, albeit in different compartments, it is doubtful that the polyclonal antibodies from two rabbits used in these experiments are preferentially recognizing a modifiable epitope on $C D C 46$ but, rather, are accurately indicating the location of CDC46p.

In view of the complex regulation of $C D C 46$ at many levels, any model that we make to account for the cyclical localization of CDC46p will necessarily be speculative. We are making the reasonable assumption that CDC46 must enter the nuclear compartment for DNA replication to proceed.

One model to explain the $C D C 46$ staining pattern envisions that the actual level of CDC46p remains the same through the cell cycle and that the protein cycles back and forth between the cytoplasm and the nucleus. At present we cannot rule this model out, although to reconcile the cyclical fluctuation of mRNA with the relatively very constant total level of protein, one would have to envision either cyclical degradation coincident with synthesis or some kind of mechanism limiting translation of the cyclically made mRNA. Detailed kinetic analysis of CDC46 synthesis at the protein level will be required to shed more light on these issues.

We prefer a second model designed to account for the complex regulatory program observed. In this model, (1) CDC46p is briefly synthesized late in the cell cycle, as suggested by our RNA level measurements, and accu- 
mulates in the cytoplasm; (2) CDC46p is specifically translocated into the nucleus immediately after anaphase, by a process possibly involving a post-translational modification such as protein phosphorylation; $|3|$ translocation is essentially complete before cells pass start, the beginning of the cell cycle; and (4) the CDC46p in the nucleus, having performed its essential function, presumably in initiation of DNA replication, is degraded during the $S$ phase.

We note several features of our results that support different aspects of this model. First, the notion that CDC46p is made and accumulates in the cytoplasm is supported by the observation (both by immunofluorescence and by fractionation) that high levels of CDC46p accumulate in the cytoplasm in arrested $t u b 2$ cells. This result, more than any other feature, suggests to us that translocation into the nucleus is not simply a concentration-dependent process. Second, the rapid, specific translocation step is supported by our observation that we found two classes of large budded cells with nuclei that had already been separated: those with CDC46p mainly in the cytoplasm and those with the protein apparently entirely in the nucleus. This stage of the cell cycle is very short, suggesting a rapid process. Modification of the protein seems like an attractive mechanism to account for the apparent rapidity and completeness of the translocation. Third, the swift degradation of the nuclear CDC46p is supported by the rapidity of disappearance of antigen from the nucleus at just the time that synthetic rates (as estimated from the mRNA levels) should be maximal.

In conclusion, we believe that in CDC46, we have identified an essential function that must act just once during the cell cycle. The function of CDC46 appears to be some aspect of initiation of DNA replication and probably takes place in the nucleus. We hypothesize that the cyclical nuclear localization of the protein guarantees that the function will be carried out only at the correct point in the cell cycle, because the protein is not present in the nucleus at other, inappropriate times. It is likely that CDC46 is only one of a number of genes (SWI5 may be another) with nuclear functions that are prevented from acting at the wrong time by being admitted to the nucleus only at the right time. It remains to be discovered whether all such genes share the same mechanism of cyclical nuclear localization.

\section{Materials and methods}

\section{Strains and media}

Yeast media and genetic manipulations have been described by Sherman et al. (1974). S. cerevisiae strains used in this study are listed in Table 2. The cold-sensitive $c d c$ mutant, CC30 /Moir et al. 1982\}, which arrests with a large bud at $18^{\circ} \mathrm{C}$, has been named $c d c 54-1$. The $c d c 46-1$ allele is described as the rA18-95 isolate (Moir et al. 1982). Bacterial media were as described in Davis et al. (1980). The Escherichia coli strain that was used for routine cloning, HB101 (DB1142), has the genotype: leu- pro $^{-}$ thr $r^{-} h s d R^{-} h s d M^{-} r e c A^{-}$.

\section{Isolation of the cdc46 gene}

A YCp50 library of $S$. cerevisiae DNA (pRB236; Rose et al. 1987) was used to transform (Ito et al. 1983; Kuo and Campbell 1983) a cdc46-1, ura3-52 strain, DBY2028. Transformants were selected on minimal plates lacking uracil at $26^{\circ} \mathrm{C}$ and for complementation of the $c d c 46$ defect at $37^{\circ} \mathrm{C}$. Plasmid DNA from pRB541 was purified from a complementing clone (Hoffman and Winston 1987) and was used to transform the E. coli strain $\mathrm{HB} 101$.

\section{Tn10-LUK mapping}

Because the Tn10-lacZ-kan ${ }^{R}-U R A 3$ (Tn10-LUK; Huisman et al. 1987/ carries the $U R A 3$ gene as its yeast marker, it was necessary to replace the YCp50 URA3 gene with a LEU2 marker. This was done in vivo by site-specific recombination in yeast (Ma et al. 1987). pRB54l was linearized by digestion with the restriction enzyme SmaI, which only cuts pRB54l within $U R A 3$, and mixed with the YEp21 SphI-PvuII fragment that holds the LEU2 gene (Botstein et al. 1979) prior to transformation of the yeast DBY2028. DNA from $\mathrm{Leu}^{+}, \mathrm{Ura}^{-}$yeast transformants was isolated, and plasmids were recovered by transformation of the $E$. coli strain DBI328. Transpositions were carried out as described (Huisman et al. 1987), and DNA purified from pooled $\mathrm{Kan}^{\mathrm{R}}$ colonies was used to transform the yeast strain DBY2028. Uracil prototrophic yeast strains were screened for the ability to complement the $c d c 46$ defect at $37^{\circ} \mathrm{C}$. The location of each transposon was subsequently determined by restriction enzyme analysis of plasmids recovered from E. coli.

\section{Disruption of the CDC46 gene}

The 1.1-kb BamHI fragment from pRB541 (Fig. 2) was cut as a band from a SeaPlaque agarose gel (FMC; Rockland, ME) and ligated into the BamHI site of the yeast integration plasmid YIp5 (Botstein et al. 1979; Struhl 1985). After bacterial amplification, the resulting plasmid was linearized with either $X b a I$ (which cuts within the 1.1-kb insert) or $\mathrm{Ncol}$ /which cuts in the plasmid URA3 genel and used to transform the diploid yeast strain DBY5450. Transformant strains with and without temperature-sensitive phenotypes were recovered, and their meiotic products.were dissected. The presence of the disruption was detected in the viable meiotic progeny, and that of the diploid parents was detected by DNA hybridization using a ${ }^{32} \mathrm{P}-\mathrm{la}$ beled CDC46 1.1-kb BamHI fragment as probe.

\section{Bacterial expression}

The same 1.1-kb BamHI fragment from pRB541 that was used for disruptions was ligated into the series of bacterial expression vectors: pATH1, pATH10, and pATH11. Each of these three vectors has a BamHI site in a different reading frame of the $\operatorname{trp} E$ gene (Dieckmann and Tzagoloff 1985). Proteins from the six RRl bacterial clones leach carrying one of the three vectors with the insert in one of two orientations/ were analyzed by SDS-PAGE and immunoblotted with anti-trpE antibodies (Harlow and Lane 1988). One of these, pRB1351, produced a fusion protein that was isolated as an insoluble pellet after lysozyme, Nonidet P-40 (NP-40) lysis. This fraction was purified further by SDS-PAGE, and the gel containing the fusion protein was injected into rabbits with Freund's adjuvant (Harlow and Lane 1988). 
Table 2. Genotype and source of strains

\begin{tabular}{|c|c|c|}
\hline Strain & Genotype & Source \\
\hline DBY2028 & MATa ura3-52 ade2-1 lys2-801 leu2-3,112 cdc46-1 & this study \\
\hline DBY1104 & MATa ade2-1 cdc46-1 & Moir et al. (1982) \\
\hline DBY901 & MATa tyr1 cdc28-1 & this lab \\
\hline DBY1173 & MATa $c d c 7-1$ his $4-912$ can 1 & this lab \\
\hline DBY1169 & MATa ade1 ade2 ura1 lys2 tyr1 gal1 his 7 cdc4-1 & Hartwell (1973) \\
\hline DBY848 & MATa his4.619 cdc9 & this lab \\
\hline DBY2058 & MATa ura3-52 his $4-619$ & this lab \\
\hline DBY5449 & $\begin{array}{l}\text { MAT } / \text { /MATa ura3-52: cdc464 : URA3 / ura3-52 leu2-3.112/LEU2 ade2-1/ADE2 lys2-801 / } \\
\text { LYS2 his4-619/ HIS4 cdc46-1/ CDC46 }\end{array}$ & this study \\
\hline DBY4921 & $\begin{array}{l}\text { MAT } / \text { MATa ura3-52 / ura3-52 leu2-3,112/LEU2 ade2-1/ADE2 lys2-801/LYS2 his4.619/ } \\
\text { HIS4 cdc46-1/cdc46: URA3:cdc46 }\end{array}$ & this study \\
\hline DBY4922 & $\begin{array}{l}\text { MATa/MATa ura3-52 / ura3-52 leu2-3,112/LEU2 ade2-1/ADE2 lys2-801 / LYS2 his4-619/ } \\
\text { HIS4 cdc46: URA3 : cdc46/CDC46 }\end{array}$ & this study \\
\hline DBY5450 & $\begin{array}{l}\text { MATa/MATa ura3-52 / ura-352 leu2-3,112 / LEU2 ade2-1/ADE2 lys2-801 / LYS2 his4-619/ } \\
\text { HIS4 cdc46-1 / CDC46 }\end{array}$ & this study \\
\hline DBY1034 & MATa his4-539 lys2-801 ura3-52 & this lab \\
\hline DBY1826 & MATa ade2-101 his3-4200 leu2-3,112 ura3-52 & this lab \\
\hline DBY 1515 & MATa his1-315 lys2-801 ade2-101 trp1- 11 tub2-104 & Thomas (1985) \\
\hline KH195 & MATa/MATa ura3-52 / URA3 hom3 / HOM3 can $\mathrm{R}^{\mathrm{R}} /$ CAN lys2-801 / LYS2 his4-619/ HIS4 & this study \\
\hline KH208 & $\begin{array}{l}\text { MATa/MATa ura3-52/URA3 hom3/HOM3 can / CANs lys2-801/LYS2 his4-619/HIS4 } \\
\text { cdc46-1/cdc46-1 }\end{array}$ & this study \\
\hline
\end{tabular}

\section{Antibody purification}

Two milligrams of gel-purified CDC46-trpE fusion protein was electroeluted (ISCO electrophoretic sample concentrator; Lincoln, NE) and coupled to a CNBr-activated Sepharose-4B (Pharmacia; Piscataway, NI) matrix. Coupling was carried out as suggested by the manufacturer, except $0.1 \%$ SDS was added to the reaction to solubilize the fusion protein. A column with coupled trpE protein was prepared similarly. The trpE protein reactivity was removed from crude rabbit serum by incubating $10 \mathrm{ml}$ of serum with $2 \mathrm{ml}$ of packed, boiled, and sonicated trpEexpressing bacteria. This mixture was clarified by spinning at $30,000 \mathrm{~g}$ for $30 \mathrm{~min}$, and the process was repeated again. Residual $\operatorname{trp} E$ reactive antibodies were removed by passing the purified serum over a $\operatorname{trp} E$ affinity column. The remaining antibodies were then loaded onto the CDC46-trpE fusion affinity column and eluted with $4.5 \mathrm{M} \mathrm{MgCl}_{2}$ and $10 \mathrm{mM}$ Tris $\{\mathrm{pH} 7.0\}$, followed by $100 \mathrm{~mm}$ glycine-HCI ( $\mathrm{pH}$ 2.5) (Bio-Rad bulletin 1099; Pringle et al. 1989). These highly purified antibodies were used in all subsequent experiments except for those using the cell fractionation samples (see below). Finally, serum from a second rabbit was purified as described above to allow comparison of the two preparations.

\section{Immunofluorescence}

Using the protocol of Kilmartin and Adams 1984; Pringle et al. 1989|, cells were fixed in growth media with $3.7 \%$ formaldehyde for $1 \mathrm{hr}$, and the walls were digested with $100 \mu \mathrm{g} / \mathrm{ml} \mathrm{Zy-}$ molyase 100T (ICN; Lisle, IL) and dried onto polylysine-coated multiwell slides (Polyscience; Warnington, PA). After methanol-acetone fixation, the slides were rehydrated in phosphate-buffered saline (PBS) and blocked with $100 \mu \mathrm{g} / \mathrm{ml}$ bovine serum albumin (BSA) in PBS. The primary antibodies were YOL1/34, anti-yeast/anti-tubulin, diluted 1/250 (Kilmartin et al. 1982 ) or affinity-purified rabbit anti-CDC46-trpE fusion protein. Both were incubated with fixed cells for $2 \mathrm{hr}$ at $22^{\circ} \mathrm{C}$ and washed with PBS at least four times. The secondary antibodies were fluorescein-labeled goat anti-rat IgG and rhodamine-labeled goat anti-rabbit IgG (Cappel, Malverne, PA), diluted 1/300 in PBS, and each was reacted two times in an alternating cycle resulting in a greatly amplified signal. Fluorescein-labeled goat anti-rat $\operatorname{IgG}$ was prereacted with Sepharose-rabbit $\operatorname{IgG}$, and rhodamine-labeled goat anti-rabbit IgG was prereacted with Sepharose-rat IgG to remove any cross-reactions. After each incubation with cells for $1 \mathrm{hr}$ at $22^{\circ} \mathrm{C}$, the slides were washed at least four times with PBS. The cell DNA was stained with 1 $\mathrm{mg} / \mathrm{ml}$ of DAPI $\left(4^{\prime}, 6^{\prime}\right.$-diamidino-2-phenylindole $)$ in PBS for 5 $\mathrm{min}$, followed by at least four washes of PBS.

\section{Cell fractionation}

Fractionation was carried out using the protocol of Goto and Wang (Goto et al. 1984). Arrested yeast cultures were washed, and the walls were digested with $100 \mu \mathrm{g} / \mathrm{ml}$ zymolyase $\mathrm{T} 100$ in a mixture of $1 \mathrm{M}$ sorbitol, $20 \mathrm{~mm}$ potassium phosphate $(\mathrm{pH} 6.8)$, $0.5 \mathrm{mM} \mathrm{CaCl}_{2}$, and $0.5 \% \beta$-mercaptoethanol. The spheroplasts were spun through a sorbitol step gradient at $2500 \mathrm{~g}$ for $5 \mathrm{~min}$ to remove proteases, resuspended in a mixture of $18 \%$ Ficoll (Pharmacia; Piscataway, NJ), $20 \mathrm{~mm}$ potassium phosphate $\{\mathrm{pH}$ $6.81,0.5 \mathrm{mM} \mathrm{CaCl}_{2}$ and $0.5 \% \beta$-mercaptoethanol, and $1 \mathrm{~mm}$ PMSF and lysed by Dounce homogenization. Unlysed cells were removed by centrifugation at $4500 \mathrm{~g}$ for $5 \mathrm{~min}$. The lysate ("total" fraction) was spun at $30,000 \mathrm{~g}$ for $30 \mathrm{~min}$ to pellet a crude nuclear fraction and leave a supernatant, which is the cytoplasmic fraction. All fractions from each fractionation experiment were normalized to the same volume to allow comparison of the three fractions on a per cell basis. DAPI-stained nuclei were detected by observation through an epifluorescence microscope with differential interference contrast optics.

\section{Determination of yeast cell DNA content}

Whole diploid cells of yeast strains KH195 and KH208 were prepared for the fluorescence-activated cell sorter by staining 
with propidium iodide (Hutter et al. 1978). Briefly, cells were ethanol-fixed and treated overnight with $0.1 \%$ RNase, followed by $5 \mathrm{mg} / \mathrm{ml}$ proteinase $\mathrm{K}$ prior to incubation in $5 \mathrm{mg} / \mathrm{ml}$ propidium iodide. The propidium iodide was removed immediately prior to running each sample through a Cytofluorograph System (Ortho Diagnostic Systems, Westwood, MA).

\section{Functional ordering}

The methods for arresting the cell cycle and shifting from one cell cycle inhibitor to another are described in detail elsewhere (Moir and Botstein 1982). After arresting an exponentially growing cdc46-1 culture (DBY1104) at the beginning of the cell cycle with $2 \mu \mathrm{g} / \mathrm{ml} \alpha$-factor (Sigma), the $\alpha$-factor was removed and the cells were washed. They were then sonicated briefly to remove clumps and incubated in fresh YEPD with $0.1 \mathrm{M}$ hy. droxyurea for $150 \mathrm{~min}$. The second condition was imposed by spotting the hydroxyurea-arrested cells on an agar slab after a brief wash in warm media. The position of each cell in the cell cycle was recorded by photography before and after the second incubation on the agar slab.

\section{RNA analysis}

Yeast strain DBY1826 was synchronized by $\alpha$-factor arrest. Cells were grown in YEPD $(\mathrm{pH} 4.0)$ to $0.8 \times 10^{6} \mathrm{cells} / \mathrm{ml}$ at $30^{\circ} \mathrm{C}$. Trial experiments determined that $2.5 \mu \mathrm{g} / \mathrm{ml}$ of $\alpha$-factor (Sigma) was the least amount needed to assure arrest. After $3 \mathrm{hr}$ of incubation in the presence of $\alpha$-factor, the culture was rinsed twice with water and resuspended in YEPD $|\mathrm{pH} 4.0|$, and 10-ml aliquots were removed at each time point for RNA extraction. In addition, aliquots were saved in $3.7 \%$ formaldehyde, sonicated, and scored microscopically for bud counts. Total yeast RNA was isolated as described (Carlson and Botstein 1982). For RNA blots and hybridization analysis, we followed the instructions for Genescreen Plus (New England Nuclear), using the dextran sulfate method. DNA fragments used as probes were as follows: for HTB2, a 1.3-kb HindIII restriction fragment containing the $3^{\prime}$ region of the HTB2 gene (Hereford et al. 1979); for $A C T 1$, a $1.6-\mathrm{kb}$ HindIII-BamHI restriction fragment internal to the coding sequence $(\mathrm{Ng}$ and Abelson 1980); for CDC46, a 1.1kb BamHI internal restriction fragment (see Fig. 2). Labeled DNA probes were prepared by random oligonucleotide labeling (Feinberg and Vogelstein 1983) in the presence of ${ }^{32} \mathrm{P} / \mathrm{dCTP}$ (3000 Ci/mmole, New England Nuclear).

\section{Acknowledgments}

We are grateful to Kai-uwe Froehlich for the initial isolation of the CDC46 gene and Allison Adams, Nava Segev, and Tim Huffaker for helpful discussions. We also thank Daphne Preuss for critical reading of this manuscript.

The publication costs of this article were defrayed in part by payment of page charges. This article must therefore be hereby marked "advertisement" in accordance with 18 USC section 1734 solely to indicate this fact.

\section{References}

Beach, D., B. Durkacz, and P. Nurse. 1982. Functionally homologous cell cycle control genes in fission yeast and budding yeast. Nature 300: 706-709.

Blow, J. and R. Laskey. 1988. A role for the nuclear envelope in controlling DNA replication within the cell cycle. Nature 332: $546-548$.
Botstein, D., S.C. Falco, S. Stewart, M. Brennan, S. Sherer, D. Stinchcomb, K. Struhl, and R. Davis. 1979. Sterile host yeasts (SHY): A eukaryotic system of biological containment for recombinant DNA experiments. Gene 8: 17-24.

Budd, M.E., K.D. Wittrup, J.E. Bailey, and J.L. Campbell. 1989. DNA polymerase $I$ is required for premeiotic DNA replication and sporulation but not for X-ray repair in Saccharomyces cerevisiae. Mol. Cell. Biol. 9: 365-376.

Burgers, P.M. 1989. Eukayotic DNA polymerases $\alpha$ and $\delta$ : Conserved properties and interactions, from yeast to mammalian cells. Prog. Nucleic Acid Res. Mol. Biol. 37: 235-280.

Carlson, M. and D. Botstein. 1982. Two differentially regulated mRNAs with different $5^{\prime}$ ends encode secreted and intracellular forms of yeast invertase. Cell 28: 145-154.

Carson, M.J. 1987. CDC17, the structural gene for DNA polymerase I of yeast: Mitotic hyperrecombination and effects on telomere metabolism. Ph.D. thesis, University of Washington, Seattle.

Courchesne, W.E., R. Kunisawa, and J. Thorner. 1989. A putative protein kinase overcomes pheromone-induced arrest of cell cycling in S. cerevisiae. Cell 58: 1107-1119.

Davis, R., D. Botstein, and J. Roth. 1980. Advanced bacterial genetics. Cold Spring Harbor Laboratory, Cold Spring Harbor, New York.

Dieckmann, C.L. and A. Tzagoloff. 1985. Assembly of the mitochondrial membrane system. I. Biol. Chem. 260: 15131520 .

Draeta, G., F. Luca, J. Westendorf, L. Brizuela, J. Ruderman, and D. Beach. 1989 . cdc2 protein kinase is complexed with both cyclin A and B: Evidence for proteolytic inactivation of MPF. Cell 56: 829-838.

Elion, E.A., P.L. Grisafi, and G.R. Fink. 1990. FUS3 encodes a $\mathrm{cdc} 2+/$ CDC28-related kinase required for the transition from mitosis into conjugation. Cell 60: 649-664.

Fangman, W.L. and V.A. Zakian. 1981. Genome structure and replication. In The molecular biology of the yeast Saccharomyces. Life cycle and inheritance (ed. J.N. Strathern, E.W. Jones, and J.R. Broachl, pp. 27-58. Cold Spring Harbor Laboratory, Cold Spring Harbor, New York.

Feinberg, A. and B. Vogelstein. 1983. A technique for radiolabeling DNA restriction endonuclease fragments to high specific activity. Anal. Biochem. 132: 6-13.

Goto, T., P. Laipis, and J.C. Wang. 1984. The purification and characterization of DNA topoisomerased I and II of the yeast Saccharomyces cerevisiae. I. Biol. Chem. 259: 1042210429.

Harlow, E. and D. Lane. 1988. Antibodies, a laboratory manual. Cold Spring Harbor Laboratory, Cold Spring Harbor, New York.

Hartwell, L.H. 1976. Sequential function of gene products relative to DNA synthesis in the yeast cell cycle. I. Mol. Biol. 104: $803-817$.

Hereford, L.M. and L.H. Hartwell. 1974. Sequential gene function in the initiation of Saccharomyces cerevisiae DNA synthesis. I. Mol. Biol. 84: 445-461.

Hereford, L., K. Fahrner, J. Woolford, M. Rosbash, and D. Kaback. 1979. Isolation of yeast histone genes H2A and H2B. Cell 18: $1261-1271$.

Hoffman, C.S. and F. Winston. 1987. A ten-minute DNA preparation from yeast efficiently releases autonomous plasmids for transformation of Escherichia coli. Gene 57: 267-272.

Huisman, O., W. Raymond, K.-U. Froelich, P. Errada, N. Kleckner, D. Botstein, and M.A. Hoyt. 1987. A Tn10-lacZkanR-URA3 gene fusion transposon for insertion mutagenesis and fusion analysis of yeast and bacterial genes. Genetics 116: 191-199. 
Hutter, K.J. and H.E. Eipel. 1978. Flow cytometric determinations of cellular substances in algae, bacteria, molds and yeast. Antonie Leeuwenhoek /. Microbiol. Serol. 44: 269282.

Ito, H., Y. Fukuda, K. Murata, and A. Kimura. 1983. Transformation of intact yeast cells treated with alkali cations. I. Bacteriol. 153: 163-168.

Johnston, L.H. and K.A. Nasmyth. 1978. S. cerevisiae cell cycle mutant $c d c 9$ is defective in DNA ligase. Nature 274: 891 894.

Kilmartin, J. and A.E.M. Adams. 1984. Structural rearrangements of tubulin and actin during the cell cycle of the yeast Saccharomyces. I. Cell Biol. 98: 922-933.

Kilmartin, I., B. Wright, and C. Milstein. 1982. Rat monoclonal anti-tubulin antibodies derived by using a new nonsecreting rat cell line. I. Cell Biol. 93: 576-582.

Kuo, C. and J.L. Campbell. 1983. Cloning of Saccharomyces cerevisiae DNA replication genes: Isolation of the CDC8 gene and two genes that compensate for the $c d c 8-1$ mutation. Mol. Cell. Biol. 3: 1730-1737.

Lee, M.G. and P. Nurse. 1987. Complementation used to clone a human homolog of the fission yeast cell cycle control gene cdc2. Nature 327: 31-35.

Lewin, B. 1990 . Driving the cell cycle: $M$ phase kinase, its partners, and substrates. Cell 61: 743-752.

Ma, H., S. Kunes, P.J. Schatz, and D. Botstein. 1987. Construction of plasmids by recombination in yeast. Gene 58 : $201-$ 216.

Minshull, J., J. Pines, R. Golsteyn, N. Standart, S. Mackie, A. Colman, J. Blow, J.V. Ruderman, M. Wu, and T. Hunt. 1989. The role of cyclin synthesis, modification and destruction in the control of cell division. In The cell cycle led. R. Brooks, T. Hunt, P. Fantes, and D. Wheatleyl, pp. 77-98. The Company of Biologists Limited, Cambridge, England.

Moir, D. and D. Botstein. 1982. Determination of the order of gene function in the yeast nuclear division pathway using cs and ts mutants. Genetics 100: 565-577.

Moir, D., S.E. Stewart, B.C. Osmond, and D. Botstein. 1982. Cold-sensitive cell-division-cycle mutants of yeast: Properties and pseudoreversion studies. Genetics 100: 547-564.

Moreno, S. and P. Nurse. 1990. Substrates for p34 cdc2: In vivo veritas? Cell 61: 549-551.

Nasmyth, K., A. Seddon, and G. Ammerer. 1987. Cell cycle regulation of SW15 is required for mother-cell-specific $\mathrm{HO}$ transcription in yeast. Cell 49: 549-558.

Nasmyth, K., G. Adolf, D. Lydall, and A. Seddon. 1990. The identification of a second cell cycle control on the HO promoter in yeast: Cell cycle regulation of SWI5 nuclear entry. Cell 62: 631-647.

$\mathrm{Ng}, \mathrm{R}$. and I. Abelson. 1980. Isolation of the gene for actin in Saccharomyces cerevisiae. Proc. Natl. Acad. Sci. 77: 39123916.

Nurse, P. 1990. Universal control mechanism regulating onset of M-phase. Nature 344: 503-508.

Pringle, J.R. and L.H. Hartwell. 1981. The Saccharomyces cerevisiae cell cycle. In The molecular biology of the yeast Saccharomyces. Life cycle and inheritance (ed. I.N. Strathern, E.W. Jones, and J.R. Broach|, pp. 97-142. Cold Spring Harbor Laboratory, Cold Spring Harbor, New York.

Pringle, J.R., R.A. Preston, A.E.M. Adams, T. Stearns, D. Drubin, B.K. Haarer, and E. Jones. 1989. Fluorescence microscopy methods for yeast. Methods Cell Biol. 31:357435.

Richardson, H.E., C. Wittenberg, F. Cross, and S.I. Reed. 1989. An essential G1 function for cyclin-like proteins in yeast Cell 59: 1127-1133.
Rose, M.D., P. Novick, 1.H. Thomas, D. Botstein, and G.R. Fink. 1987. A Saccharomyces cerevisiae genomic plasmid bank based on a centromere-containing shuttle vector. Gene 60: $237-243$.

Sherman, F., G. Fink, and C. Lawrence. 1974. Methods in yeast genetics. Cold Spring Harbor Laboratory, Cold Spring Harbor, New York.

Sitney, K.C., M.E. Budd, and J.L. Campbell. 1989. DNA polymerase III, a second essential DNA polymerase, is encoded by the $S$. cerevisiae CDC2 gene. Cell 56: 599-605.

Slater, M.L. 1973. Effect of reversible inhibition of deoxyribonucleic acid synthesis on the yeast cell cycle. I. Bacteriol. 113: $263-270$

Stillman, B. 1989. Initiation of eukaryotic DNA replication in vitro. Annu. Rev. Cell Biol. 5: 197-245.

Struhl, K. 1985. A rapid method for the creating recombinant DNA molecules. BioTechniques 3: 452-453.

Wittenberg, C. and S.I. Reed. 1989. Conservation of function and regulation within the $C d c 28 / c d c 2$ protein kinase family: Characterization of the human $\mathrm{Cdc} 2 \mathrm{Hs}$ protein kinase in Saccharomyces cerevisiae. Mol. Cell. Biol. 9: 40644068 . 


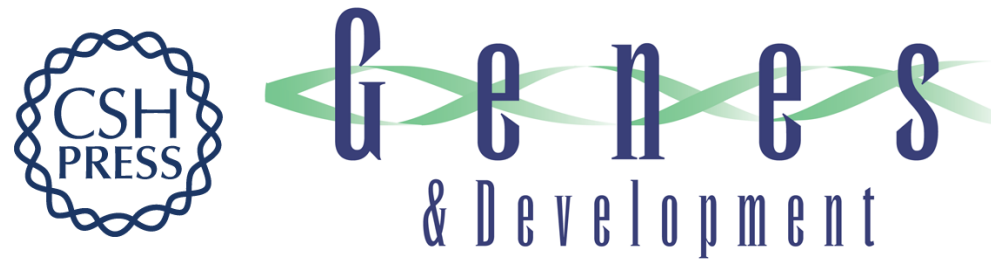

\section{Subcellular localization of yeast CDC46 varies with the cell cycle.}

K M Hennessy, C D Clark and D Botstein

Genes Dev. 1990, 4:

Access the most recent version at doi:10.1101/gad.4.12b.2252

References This article cites 41 articles, 13 of which can be accessed free at: http://genesdev.cshlp.org/content/4/12b/2252.full.html\#ref-list-1

License

Email Alerting

Receive free email alerts when new articles cite this article - sign up in the box at the top Service right corner of the article or click here.

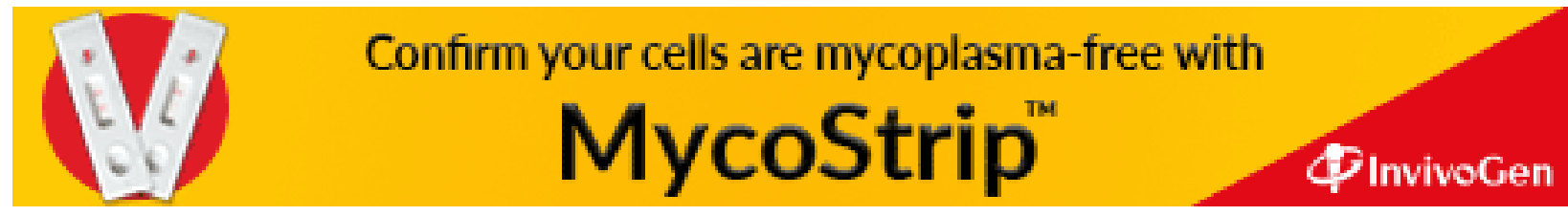

